\title{
The Impact of School Culture on Social, Independent And Disciplined Characters on Elementary Students In The District Mranggen Districts Of Demak
}

\author{
Shohib \\ \{shohib909@gmail.com\} \\ Faculty of Teaching and Education, Universitas Muria Kudus Gondang Manis PO. BOX 53 Bae, Kudus \\ Central Java, Indonesia Phone (+62291) 438229, Fax (+62291) 437198
}

\begin{abstract}
The purpose of this research is (1) find out how much the impact of school culture on social character development in elementary students; (2) knowing how much the impact of school culture on developing independent character in elementary students; (3) find out how much impact the school culture has on the development of the character of discipline in elementary school students; (4) knowing the highest character impact of the application of school culture to the development of social, independent, and disciplined characters in elementary students. The number of student violations that occur at school such as being late for school, students skipping during study hours, lazy learning, often not attending school, not doing assignments given by the teacher, not doing homework, etc. This has received attention from school institutions by implementing policies such as applying school culture to have an impact on good character for students. This method of research uses quantitative research. Research subjects include principals and high-class elementary school students in Demak district. The data collection techniques used are interviews, polls, and documentation. Sampling techniques using random sampling techniques. The data analysis technique uses data analysis techniques of correlation, regression, and ANOVA testing. The results showed that (1) there was the impact of the school's culture on social characters with the correlation 0.638 (2) There was a school culture impact on the independent character with the correlation 0.294 (3) There was a school culture impact on the character discipline with the correlation 0.335 . The highest cultural impact is on social character.
\end{abstract}

Keywords: culture, school, character, social, independent, and discipline

\section{INTRODUCTION}

Reality in the field shows that there are still many educational organizations in this school, yet produce quality output because of the learning process and the character of the culture has not been good. School culture seems to be a monotonous rule and a mere slogan because of its rules but rarely implemented. The school still tends to maintain the old school's habits and policies, although it is sometimes outdated.

Anden (2013:168-169) suggests that school culture is an adoption of the organizational culture, which is the norm that tells people what it's welcome and what it doesn't, the dominant values that the organization has appreciated The organization's main rules, a philosophy that is adopted by an organisation in interacting with people inside or outside the organization. 
As a typical character embraced by all members of the school, school culture can be a guide that provides a good framework and foundation in the form of ideas, spirits, ideas, and ideals that lead the performance of teachers to achieve school objectives and quality Expected education. This is in line with the thought of Ansar and Masaong (2011:187) that suggests that the school culture affects how the work is done as well as how the school citizens behave. Thus the culture prevailing in the school run by its members, plays an important role in improving the quality of the Members ' performance in it.

Researchers conducted research at Mranggen Elementary School in Demak District, because reality in the field is still found learners who level of social character, independent, and discipline is still low.

The problem formulation in this study is: 1) How does the school's cultural impact on the development of the social character of elementary students?. 2) How the school's cultural impact on the development of independent-character elementary students. 3) How to impact the school culture on the development of the discipline character of elementary students? 4) What is the highest character impact of the school's cultural implementation on the development of social, independent, and disciplined character in elementary students?

The purpose of this research was to: 1) Find the school's cultural impact on the development of student social character. 2) Find the school's cultural impact on the development of students independent character. 3) Find the school's cultural impact on the development of student discipline character. 4) Describing the highest character impact of the school's cultural implementation on the development of social, independent and disciplined character in elementary students.

This research is expected to provide benefits for teachers to add knowledge development and insight into the impact of school culture on the social character, independent, and the discipline of SD students in the district Mranggen district of Demak, can help teachers In carrying out its task to be able to improve the quality of learning based on the planting of values of social character, independent, and discipline, and make students understand that the success of education is not only measured from cognitive but Also characters including social, self-reliant, and discipline.

Marzuki (in Supardi (2014:121), school culture is a cultural condition around school and a comfortable atmosphere that is suitable and conducive to learning which can improve academic achievement. According to Creamers and Scheerens (in Supardi (2014:121), school culture depicts the cultural state of all the school residents in a harmonious, friendly or caring manner. A friendly relationship to school culture occurs because there is a good relationship between the principal, the teacher, and the learners.

Hoy and Miskel (2008:234), school culture are: "School culture climate is a relatively enduring quality of the school environment that is experienced by participants, affects their behavior, and is based on their collective perceptions of behavior in school".

According to Rivai and Murni (2009:231) school culture is a characteristic that distinguishes one school from another and that it affects the individual behaviour of the school organization. They further explain that school culture is a broad requirement that refers to teacher perception to the main working environment of the school, the formal organization, the informal, the personality of the participants, and the leader of the organization that influenced it.

From the explanation above it can be interpreted that school culture is the totality of habits and behaviors that appear in school society, including the enforcement, belief, art, norms, beliefs, morals, hopes, and abilities gained as members Community of school citizens.

Lickona (in Imas Kurniasih \& Berlin Sani 2017:78) states that three components of good character include moral knowing (knowledge of morals), moral feeling (feelings of moral), 
moral action (moral deeds). So with these components, one is expected to be able to understand, feel, and work on religious values, social norms, regulations or laws, academic ethics, and principles of human rights.

Lickona (in Wibowo 2012:32) explains that character is a person's natural nature in responding to the situation immoral. This natural nature is manifested in real action through good behaviour, honesty, responsibility, respect for others, and other noble characters.

Jack Corley and Thomas Philip in the Samani (2016:42) Declare the character a person's attitude and habit of enabling and easing moral action. The character building process is a long journey. It takes steps to be passed by anyone who wants to form a character, including social, self-reliant, and disciplined characters.

Social characters are attitudes and actions that always want to give help to other people and communities in need. Beron and Byrne (2005:111) states that caring is an attitude that one has to give attention to the neighbor or the surrounding environment, in this research is only focused to attention to each other because of its scope Only on social care characters.

Factor that affect a person's social character consist of: (1) genetic or congenital factors from birth; and (2) environmental factors. Genetic or congenital factor of birth is everything that has been brought from birth, both mental and physical. Environmental factors are something that exists outside the human being, both alive and dead.

The educational environment factors become one that affects the social character formation of learners in addition to environmental factors and others. The school as a formal educational institution trusted by the public to educate their children, in addition to providing science, technology, and Art, should also be able to develop aspects of moral and religious values in order Forming attitudes and behaviors of people who are noble (noble) character, so that it can be a nation that is a polite and dignified.

Social character is part of a character education that hints at the formation of human beings ' personal values. This social character is important because of the interaction of human personal interactions in his life. Social characters formed in human personal will equip them to be able to live alongside compassion, mutual respect, democratic, cooperation, peace, and mutual attention.

The word independent according to the Bahasa Indonesia dictionary is in a state of being able to stand alone; Not dependent on others. The word is self-reliance which means that things or circumstances can stand alone without relying on others. The synonym of the word independent is self-reliant, which is standing on the feet alone; not relying on the help of others.

From the above sense, Suparman (2003:31), it is that the independent character education is an education that forms morality, character, and human mentality so that his life does not depend on or rely on other parties, not dependent on the help of others. Self-esteem is aimed at the human beings who believe in themselves in the business of doing things. Independent characters encourage and spur a person to solve his or her life issues, so he is motivated to take initiative, create, innovate, proactively and work hard. The education of self-sufficient ethics spur one's courage to do or react, not be resigned and frozen, remain dynamic, energetic and always optimistic towards the future.

Discipline is one of the values of character that can be implanted in students as one attitude in learning. The Salahudin (2013:111) defines discipline as an act that demonstrates orderly behavior and adhering to various provisions and regulations. Samani (2012:121) believes that the character of discipline is the attitude and behavior that arises as a result of training or habit of obeying rules, laws or orders. 
Suryadi (2013:8). The disciplinary indicators include: 1) on-time task completion 2) reminding each other of friends so that all class assignments are carried out well, 3) always inviting friends to keep class order and classroom environment, 4) dressed modestly and neatly.

Based on the understanding, the character of discipline is a behavior by someone in order to obey the existing rules. A disciplined character is a behavior that a student can show at school.

\section{Skeletal thinking}

The cultured nation usually has a reliable and powerful human resources and can implement it in everyday life. The character of a child needs to be applied early because at an early age child character formation is easier to implement. Character education can help students to have good habits and behaviors in everyday life, whether at home, in school, or in society.

The study sought the impact of school culture on social characters, independent characters, and the discipline of elementary school students in the Mranggen sub-district of Demak district. Students ' character can be formed through a conducive school culture.

To give explanations of the framework think this research can describe as follow.

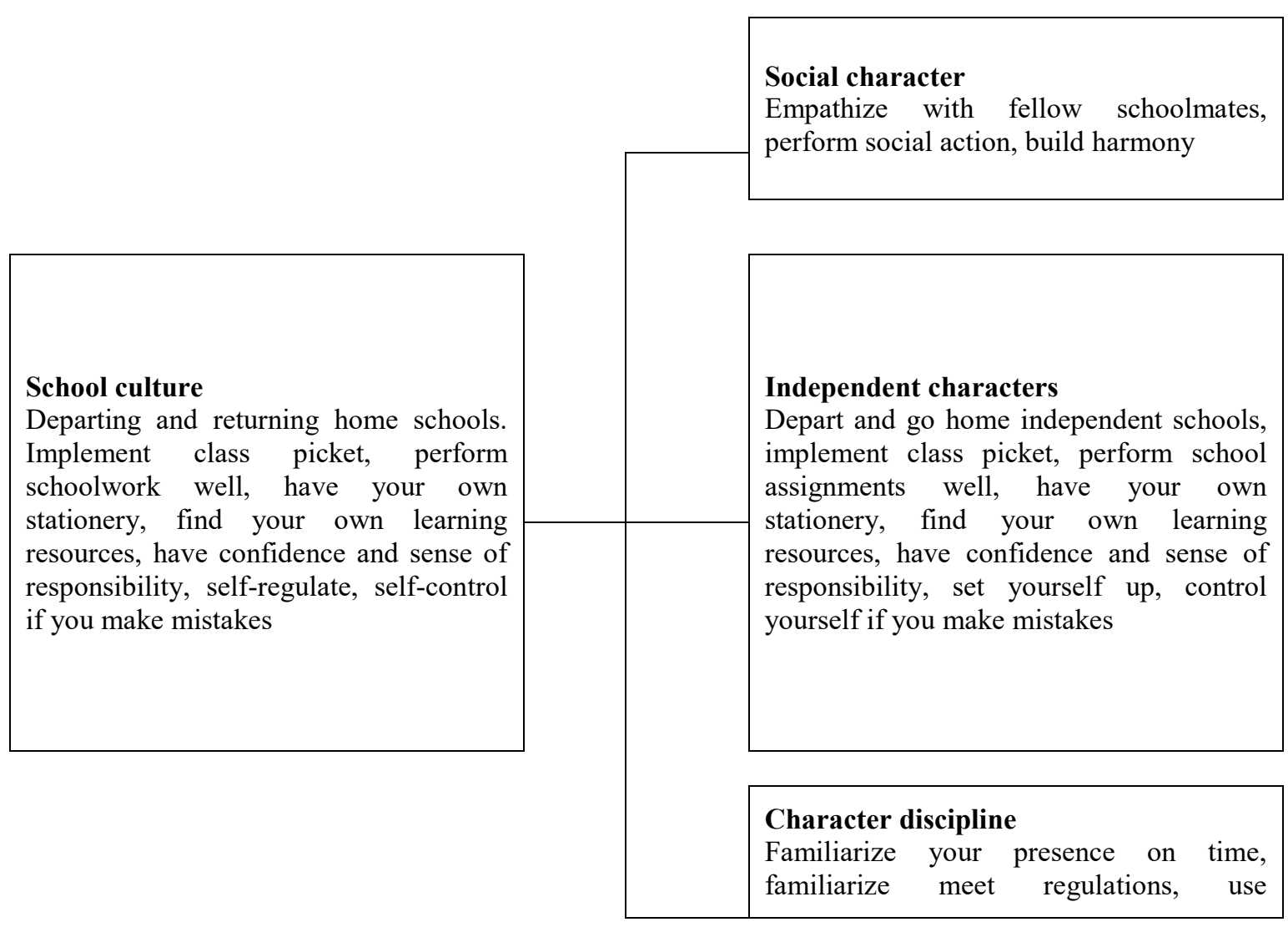


This research uses quantitative research design with multivariate analysis method because it presents the data in the form of numbers and then described using readable words.

In this research the techniques to be used in collecting data are interviews, questionnaires, and documentation.

Instruments in quantitative research can be tests, interview guidelines, observation guidelines, and questionnaires. In this research the instruments to be used are interview sheets and questionnaires.

Sugiyono (2018:335) data analysis is a process of finding and structuring systematic data obtained from interviews, field records, and documentation by organizing the data into the category, describing into units, Perform syntheses, devise into patterns, choose which are important and to be learned, and make conclusions so that they are easy to understand by themselves and others.

\section{RESULTS OF RESEARCH}

The research results of data on school culture, social characters, and discipline can be seen as follows:

Table 1. The student's category of school culture, social character, and discipline No aspect category student percentage of high-categories

\begin{tabular}{|l|l|l|l|}
\hline No & Aspect & Student Category & Percentage of high category students \\
\hline \multirow{2}{*}{1} & \multirow{2}{*}{ School culture } & High & $73 \%$ \\
\cline { 3 - 4 } & & Medium & $14 \%$ \\
\cline { 3 - 4 } & & Low & $14 \%$ \\
\hline \multirow{2}{*}{2} & \multirow{2}{*}{ Social characters } & High & $11 \%$ \\
\cline { 3 - 4 } & & Medium & $78 \%$ \\
\cline { 3 - 4 } & \multirow{3}{*}{3} & Low & $11 \%$ \\
\hline \multirow{3}{*}{4} & \multirow{2}{*}{ Discipline Characters } & High & $12 \%$ \\
\cline { 3 - 4 } & & Medium & $74 \%$ \\
\cline { 3 - 4 } & & Low & $12 \%$ \\
\cline { 3 - 4 } & & Hedium & $11 \%$ \\
\cline { 3 - 4 } & & Low & $72 \%$ \\
\hline
\end{tabular}

Testing of normality was frozen using Kolmogorov-Smirnov to variable school culture and social character, independent, and discipline. Variable Data is said to be a normal distribution if the level of significance Kolmogorov-Smirnov more than 0.05 . Summary of test results normality can be seen in table 2 .

Table 2. Normality Test Summary

\begin{tabular}{|l|l|l|l|}
\hline Variable Research & Aspect & Significance & Description \\
\hline Dependent & School culture & 0,498 & Normal \\
\hline Independent & Social character & 0,894 & Normal \\
\hline & Independent character & 0,634 & Normal \\
\hline
\end{tabular}




\section{\begin{tabular}{l|l|l} 
Discipline character & 0,630 & Normal
\end{tabular}}

Based on table 2. That all variables are normal distribution with all levels of significance of more than 0.05

Test the correlation of school culture against social characters, independent characters, and disciplined characters tested by the correlation test product moment, can be seen in the table as follows:

Table 3. Correlation of school culture with social characters

\begin{tabular}{|c|l|l|}
\hline & School_culture & Character_social \\
\hline School_culture Pearson Correlation & 1 & $.638^{* *}$ \\
Sig. (2_tailed) & & .000 \\
N & 68 & 68 \\
\hline Character_social Pearson Correlation & $.628^{* *}$ & 1 \\
Sig. (2_tailed) & .000 & 68 \\
N & 68 & \\
\hline
\end{tabular}

Interpretasi $\mathrm{r}$ menurut pearson, yaitu:

$0 \quad$ : No correlation

$>0-0,25 \quad:$ Very weak correlation

$>0,25-0,5 \quad:$ Enough correlation

$>0,5-0,7 \quad:$ Strong correlation

$>0,75-0,99 \quad:$ Very strong correlation

$1 \quad$ : Perfect correlation

From the analysis it is known that respondents as much as 68 resulted in a correlation value of 0.638 , so that the school culture variable $(\mathrm{Y})$ with the social character Variable (X1) has a very strong relationship.

Table 4. School culture correlation with Self-reliant characters

\begin{tabular}{|c|l|l|}
\hline & School_culture & Character_independent \\
\hline School_culture Pearson Correlation & 1 & .294 \\
Sig. (2_tailed) & & .086 \\
N & 68 & 68 \\
\hline Character_Independent Pearson Correlation & .294 & 1 \\
Sig. (2_tailed) & .086 & \\
N & 68 & 68 \\
\hline
\end{tabular}

From the analysis, it is known that respondents as much as 68 resulted in a correlation value of 0.294, so that the school culture variable (Y) with the Self-reliant character Variable (X2) has enough relationship.

Table 5. Correlation of school culture with character discipline

\begin{tabular}{|c|l|l|}
\hline & School_culture & Character_discipline \\
\hline School_culture Pearson Correlation & 1 & .335 \\
Sig. (2_tailed) & & .057 \\
N & 68 & 68 \\
\hline Character_discipline Pearson Correlation & .335 & 1 \\
\hline
\end{tabular}




\begin{tabular}{|l|l|l|}
\hline Sig. (2_tailed) & .057 & 68 \\
$\mathrm{~N}$ & 68 & 68 \\
\hline
\end{tabular}

From the analysis, it is known that respondents as much as 68 resulted in a correlation value of 0.335 so that the school culture variable (Y) with a variable of character discipline (X3) has enough relationship.

\section{CONCLUSION}

The conclusion of the study is that there is a significant impact between the school culture and the 0.638 social character with a strong correlation value, there is a significant impact between the school culture and the self-reliant character 0.294 with the value of Enough correlation, there is a significant impact between the school culture towards the discipline character of the 0.335 Sebasar with sufficient correlation value. From the impact of the three characters, social characters, independent characters, and disciplinary characters, the highest significant impact is the school culture with the social character of 0.638 with a strong correlation value.

\section{BIBLIOGRAPHY}

Agboola.2012. Bring Character Education into Clasroom. European Journal of Educatinal Research. 1 (2) 163-170.

Aisyah, 2014. The Implementation of Character education Through Contextual Teaching and Learning at Personality Development Unit In The Sriwijaya University Palembang. Journal of Research in Character Education. 1 (1):203-2014.

Apriani, A dan Muhammad Nur wangit, 2015. Pengaruh SSP Tematik-Integratif terhadap karakter disiplin dan tanggungjawab siswa kelas II SD. Jurnal Prima Edukasia. 3 (1) $12-25$.

Arikunto, S. 2013. Dasar-dasar Evaluasi Pendidikan. Jakarta. PT Bumi Aksara.

Arikunto, S. 2010. Prosedur Penelitian Suatu Pendekatan Praktik. Jakarta: Rineka Cipta.

Budiyanto, M dan Imam Machali, 2014. Pembentukan Karakter Mandiri Melalui Pendidikan Agriculture di Pondiok Pesantren Islamic Studies Center Aswaja Lintang Songo Piyungan Bantul Yogyakarta. Jurnal Pendidikan Karakter . IV(2); 108-122.

Daryanto dan Darmiatun, 2013. Implementasi Pendidikan Karakter di Sekolah. Yogyakarta: Gava Media.

Daryanto dan Henry, T. 2013 Pengelolaan Budaya dan iklim Sekolah. Yogyakarta: Gama Media.

Dwi Priyatno. 2010. Paham Analisa statistik Data dengan SPSS. Yogyakarta. Mediakom.

Ghozali, I. 2016. Aplikasi Analisis Multivariet dengan Program IBM SPSS 23. Semarang. Universitas Diponegoro.

Imas Kurniasih, Berlin Sani, 2017. Pendidikan Karkter Internalisasi Dan Pembelajaran Di Sekolah. Yogyakarta: Kata Pena

Koesoema A, Doni. 2012. Pendidikan Karakter Utuh dan Menyeluruh. Yogyakarta: Penerbit Kanisius.

Lickona, T. 2012. Mendidik Untuk Membentuk Karakter: Bagaimana Sekolah Dapat Memberikan Pendidikan Sikap Hormat Dan Bertanggung Jawab. Penerjemah Juma Abdu Wamaungo. Jakarta: Bumi Aksara. 
Masrukhan, A. 2016. Pelaksanaan Pendidikan Karakter Peduli Sosial di SD Negeri Kota Gede 5 Yogyakarta. Jurnal Guru Pendidikan Sekolah Dasar. 29 (5):2812-2820.

Mendikdsmen. 2010. Model Pembinaan Pendidikan Karakter di Lingkungan Sekolah. Jakarta: Kemendiknas.

Mulyasa, 2013. Pengembangan dan Implementasi Kurikulum 2013: Perubahan dan Pengembangan Kurikulum 2013 merupakan persoalan genting. Bandung: PT Remaja Rosda karya.

Natsir. M, 2003. Metode penelitian. Bandung: Universitas Padjajaran bandung.

Pasani, C.F 7 Mitra Paramita. 2014 meningkatkan Karakter Mandiri dan Hasil Belajar Matematika Siswa melalui Model Pembelajaran kooperatif Tipe Tink Pair Share (TPS) di Kelas VIII_C SMPN 13 banjarmasin. JPM IAIN Antasari. 01 (2): 17-32.

Pranowo, D.J. 2013. Implementasi Pendidikan Karakter Kepedulian dan Kerja Sama Pada Mata Kuliah Keterampilan Berbicara Bahasa Prancis dengan Metode Bermain Peran. Jurnal Pendidikan Karakter. 3 (2): 218-230.

Quin, J.L. dkk. 2015. The Correlation Between Leadership, Culture, and Student Achievement. The Online journal of New Horizons in Education. 5 (2): 55-62.

Sudrajat, A dan Ari Wibowo. 2013. Pembentukan Karakter Terpuji di Sekolah Dasar Muhammadiyah Condongcatur. Jurnal Pendidikan Karakter. 3 (2): 174-185.

Sugiyono, 2018. Metode Penelitian Pendidikan (Pendekatan Kuantitatif, Kualitatif, dan $R \& D) . \mathrm{CV}$, Alfabeta.

Supraptiningrum dan Agustini. 2015. Membangun Karakter Siswa Melalui Budaya Sekolah di Sekolah Dasar. Jurnal Pendidikan Karakter. V (2); 219-228.

Suyadi, 2015. Strategi Pembelajaran Karakter. Bandung: PT. Remaja Rosda Karya.

Wardani, K. 2014. Implementasi Pendidikan Karakter Melalui Budaya sekolah di SD Negerti taji Prambanan Klaten. ISBN: 978-602-14696-1-3.

Wening, S. 2012. Pembentukan Karakter bangsa Melalui Pendidikan Nilai. Jurnal Pendidikan Karakter. 2 (1); 55-66.

Wibowo, A. 2012. Pendidikan Karakter: Strategi membangn Karakter bangsa Peradaban. Yogyakarta: Pustaka Belajar.

Zubaidi, 2013. Desain Pendidikan Karakter: Konsepsi dan Aplikasinya dalam Lembaga Pendidikan. Jakarta: Perdana Media Grup. 